Muzeum Uniwersytetu Jagiellońskiego

anna.lohn@uj.edu.pl

\title{
Czy skutecznie docieramy do naszych stuchaczy? Badania na podstawie zajęć ze studentami Uniwersytetu Trzeciego Wieku prowadzonych w Muzeum Uniwersytetu Jagiellońskiego ${ }^{1}$
}

\section{ABSTRACT}

Are we reaching our audience effectively? Research based on classes held at the Jagiellonian University Museum with third age university students

Since 2015, the Jagiellonian University Museum has regularly partnered with the Jagiellonian University of the Third Age (JUTA) by organizing lectures for seniors on selected issues concerning the history and collections of the university. The author of this paper extensively surveyed the attendees to evaluate how much information they were able to remember. To illustrate the absorption of knowledge by seniors, the questionnaires were analyzed in terms of three questions: (1) Did most of the respondents obtain a positive (i.e. good or highly satisfactory) or negative (unsatisfactory) result? (2) Which result (unsatisfactory, good, or highly satisfactory) did the largest number of respondents achieve? (3) What was the ratio of unsatisfactory to highly satisfactory results?

The questionnaires highlighted the strongest points of the program, but also its shortcomings. Based on them, we can conclude that the lectures make a lot of sense, enriching the JUTA students with knowledge bordering on popular science as well as specialist knowledge. An important benefit of the study is feedback for those preparing and delivering the lectures.

Keywords: University of the Third Age, museum education, seniors, museum lessons, older people

Słowa kluczowe: Uniwersytet Trzeciego Wieku, edukacja muzealna, seniorzy, lekcje muzealne, osoby starsze

${ }^{1}$ Badania zostały przeprowadzone na potrzeby pracy dyplomowej zatytułowanej „Przyswajalność wiedzy przez słuchaczy Uniwersytetu Trzeciego Wieku. Badania na podstawie zajęć prowadzonych w Muzeum UJ" napisanej pod kierunkiem prof. J. Święcha w ramach Podyplomowego Studium Muzeologicznego w Instytucie Etnologii i Antropologii Kulturowej Uniwersytetu Jagiellońskiego (grudzień 2019). 
W roku 2021 mija 48 lat od powstania pierwszego Uniwersytetu Trzeciego Wieku na świecie, założonego we Francji z inicjatywy Pierre’a Vellasa ${ }^{2}$. Przez te lata zaszło wiele zmian w naszym podejściu do starości, która - jak się wydaje - jest coraz mocniej „oswajana” przez współczesne społeczeństwo, czy to za sprawą inicjatyw z dziedziny medycyny i edukacji, czy też kultury masowej i przemysłu rozrywkowego. Osoby powyżej 60. roku życia stały się w ostatnich latach znaczącym odbiorcą oferty wszelkiego rodzaju instytucji kultury, które w odpowiedzi na rosnące zainteresowanie ze strony seniorów zaczęły wzbogacać swoje programy o wydarzenia specjalnie im poświęcone 3 . Nie inaczej stało się w Muzeum Uniwersytetu Jagiellońskiego (MUJ), które od roku 2015 regularnie współpracuje z Jagiellońskim Uniwersytetem Trzeciego Wieku (UTW UJ). Wykłady dla osób starszych są obecnie - obok zajęć edukacyjnych dla dzieci istotnym punktem oferty MUJ, co skutkuje nieustannym uatrakcyjnianiem programu. O pozytywnym wpływie takich inicjatyw na starszych odbiorców wiele już napisano. Wizja postępującego starzenia się społeczeństwa wpływającego na procesy demograficzne nie mogła umknąć uwadze rzeszy ekspertów, w tym socjologów, gerontologów, antropologów przyrodniczych, demografów, ekonomistów, antropologów kulturowych, kulturoznawców, psychologów i filozofów ${ }^{4}$. Pozytywne komentarze naszych słuchaczy i ich dopytywanie o kolejne zajęcia były nie tylko nagrodą za wysiłek i zaangażowanie, ale także czynnikiem mobilizującym dla pracowników MUJ opracowujących warsztaty. Czy jednak zadowolenie słuchaczy definitywnie oznaczało, że przyjęta przez nas formuła była wystarczająca? Jaką dawkę wiedzy byli oni w stanie przyswoić podczas godzinnych zajęć i czy faktycznie zapamiętują to, co najistotniejsze?

Autorka pracy postanowiła sprawdzić, jak skutecznie dociera do naszych seniorów wiedza prezentowana na wykładach. Przeprowadzono w tym celu wiele ankiet wśród słuchaczy UTW, które uwidoczniły zarówno najmocniejsze strony programu, jak i punkty wymagające udoskonalenia. Celem ankiet było zatem pozyskanie informacji zwrotnej dla prowadzących. Wymagało to od każdego z autorów scenariusza zajęć i wytypowania faktów, na których przekazaniu najbardziej im zależało. Analiza wyników przedstawiona w jednym z kolejnych rozdziałów pokaże, w jakim stopniu ankieta może pomóc w wychwyceniu treści najsłabiej przyswajalnych przez odbiorców i stać się tym samym praktycznym narzędziem w pracy muzealnika zajmującego się działalnością edukacyjną.

\section{Jagielloński UTW}

Uniwersytet Trzeciego Wieku UJ jest jedną z najstarszych jednostek edukacyjnych w Polsce z programem przeznaczonym dla seniorów. U jego początków stoi międzyuczelniane studium powołane w 1982 roku decyzją Senatów Uniwersytetu Jagiellońskiego

2 P. Głowacki, Uniwersytet III wieku. Wyzwanie i szansa dla muzeum, „Muzealnictwo” 2013, nr 54, S. 192 .

3 Po co seniorom kultura? Badania kulturalnych aktywności osób starszych. Raport Związku Miast Polskich, Poznań 2012, s. 18.

4 Ibidem, s. 5. 
i ówczesnej Akademii Medycznej. Jego celem było rozpowszechnianie wiedzy wśród osób starszych oraz profilaktyka procesu starzenia się. Obecnie Jagielloński UTW funkcjonuje jako jednostka pozawydziałowa w pionie Prorektora ds. dydaktycznych. Po prawie 40 latach działalności oferta znacznie się wzbogaciła zarówno o kierunki wiodące, jak i seminaria fakultatywne. Studenci kształcą się na wykładach z takich dziedzin, jak historia sztuki, historia i kultura Krakowa, Chiny czy judaistyka.

Pierwszym krokiem w nawiązaniu współpracy z naszym ,,rodzimym” UTW było zaproszenie słuchaczy do zwiedzenia ekspozycji głównej. Ogromny entuzjazm kolejnych grup skłonił nas do zastanowienia się nad nieco inną formą spotkań i tak powstał w 2015 roku pierwszy program warsztatów dla seniorów przygotowany przez Dział Oświatowy. Postanowiliśmy zrezygnować z prowadzenia zajęć w przestrzeni ekspozycyjnej. Regularny ruch turystyczny uniemożliwia spędzanie w poszczególnych salach długiego czasu, a terminy spotkań należało dostosować do planu zajęć słuchaczy. W ten sposób uniknęliśmy ,zmuszania” studentów do dojazdów na teren dzielnicy uniwersyteckiej w terminach innych niż godziny ich zajęć obowiązkowych. Kolejną przeszkodą była kwestia zapewnienia miejsc słuchaczom. W salach ekspozycyjnych nie ma możliwości rozstawienia krzeseł dla kilkunastoosobowej grupy. Według badań przeprowadzonych w 2014 roku dla 74,3\% osób starszych czynnikiem istotnym przy wyborze wydarzeń kulturalnych jest zagwarantowanie miejsca siedzącego ${ }^{5}$. Zdecydowaliśmy się zatem na formułę wykładu w sali edukacyjnej, wyposażonej w rzutnik, a także w odpowiednią liczbę krzeseł i stołów. Czego jednak miałyby dotyczyć zajęcia? Największym atutem MUJ jest aranżacja kolekcji umieszczona w przestrzeni ekspozycyjnej. To właśnie sale w połączeniu z muzealiami działają na odbiorców, pozwalając na narrację skupioną wokół historii uczelni. Mimo to prowadzenie zwykłego wykładu, choćby nawet okraszonego najlepiej przygotowaną prezentacją, nie będzie się zbyt różnić od oferty, którą seniorom oferuje sam UTW. W obliczu tego dylematu zdecydowaliśmy się na połączenie dwóch elementów, tj. formuły wykładu z prezentacją obiektów. Stworzyliśmy scenariusze zajęć dotyczących historii uniwersytetu bądź wybranych obiektów z kolekcji wzbogaconych o oglądanie muzealiów na żywo. W kilku przypadkach urozmaiciliśmy zajęcia o krótką wizytę w wybranej sali muzealnej z istotnymi dla tematu eksponatami. To pozwoliło na zdynamizowanie wykładów oraz osiągnięcie tzw. efektu wow, tak ważnego w najnowszej metodyce interpretacji dziedzictwa. Po wysłuchaniu półgodzinnego wykładu, przykładowo poświęconego sztuce witrażu, słuchacze udają się do jednej z sal Collegium Maius, gdzie mogą obejrzeć bezcenne witraże. Przygotowanie teoretyczne w postaci faktów, nazw czy objaśnień technologicznych wieńczy bezpośredni kontakt z dziełem, które w takiej odsłonie wygrywa konkurencję z innymi obiektami. Cała nasza uwaga skupia się na fenomenach, o których tyle mówiliśmy przez ostatnie pół godziny. Dla naszych gości okazało się to idealnym rozwiązaniem. W takim przypadku niemożność siedzenia przez nawet 15 minut przestaje mieć znaczenie.

${ }^{5}$ M. Poprawski, Rozwój publiczności - seniorzy w instytucji kultury [w:] Rodziny/2015. Seniorki i seniorzy/2016 w instytucji kultury. Publikacja poseminaryjna cyklu „Odbiorcy instytucji kultury”, red. M. Herkt, A. Mieszała, Poznań 2018, s. 86. 
Nieco odmienną formułę musieliśmy przyjąć w przypadku zagadnień, do których obiekty znajdują się na co dzień w magazynie, na przykład odnośnie do historii technik graficznych czy losów uniwersytetu w czasie II wojny światowej. W trakcie tych zajęć wybrane muzealia są przynoszone do sali wykładowej. Wymaga to za każdym razem sporo wysiłku, zaangażowania kustoszy, a niekiedy pracowników konserwacji, bez wątpienia jednak takie urozmaicenie świetnie spełnia swoją funkcję. Obcowanie z obiektami nieudostępnianymi na co dzień, prezentowanymi w specjalnych rękawiczkach i z zachowaniem wszelkich środków ostrożności potrafi wytworzyć „,magiczną” atmosferę wokół muzealiów. Przy okazji nasi słuchacze czują się wyróżnieni, gdyż to właśnie dla nich obiekty są wyciągane ze swoje codziennej, magazynowej rzeczywistości, by ożyć na ich oczach. Czasem widać w nich zachwyt, gdy pokazujemy opracowane z jubilerską precyzją klocki Biblii Lutra, a czasem bolesną zadumę towarzyszącą oglądaniu listów z obozu koncentracyjnego z Sachsenhausen do rodzin aresztowanych profesorów.

\section{Miejsce, tematyka, a może edukatorzy - co przyciąga?}

Już od samego początku wdrażania programu dla seniorów udało się zgromadzić na wykładach większą grupę słuchaczy, tj. 15-20 osób. Zważywszy na to, że w muzealnej sali wykładowej limit wynosi 20 osób, frekwencja była dla nas jak najbardziej zadowalająca. Tutaj warto zwrócić uwagę na utrudnienia w bieżącej komunikacji z osobami starszymi. Wszelkie aktualności na temat zajęć muszą być przekazywane odpowiednio wcześnie. Przy takiej grupie odbiorców wciąż nie sprawdza się internet. W wypadku nagłej zmiany w kalendarzu wykładów musimy liczyć się z tym, że informacja zamieszczona na stronie internetowej nie zostanie odczytana przez zdecydowaną większość zainteresowanych. Wymaga to od Muzeum szczególnej zapobiegliwości przy rezerwacji przestrzeni na zajęcia czy wyznaczaniu prowadzących.

Warto się zastanowić, które czynniki pozwoliły na zyskanie i utrzymanie popularności zajęć. Sięgnijmy ponownie do statystyk poruszających kwestie istotne dla seniorów w wyborze zajęć kulturalnych. Aż dla 79,45 \% dużą rolę odgrywa ,znany wykonawca", dla 75\% zaś miejsce, sceneria, klimat ${ }^{6}$. W tym przypadku MUJ wykorzystuje w pełni swój potencjał, przyciągając nie tylko nazwą, ale także budynkiem. Zajęcia w Collegium Maius - najstarszym gmachu uniwersyteckim - który wita swoich gości arkadowym dziedzińcem i cegłami pamiętającymi czasy Kopernika, już na wstępie tworzy wymarzoną atmosferę do zgłębiania wiedzy. Dodajmy w tym miejscu, że dostęp do sali wykładowej jest dostosowany do potrzeb osób starszych. Jedna z nich znajduje się na parterze, druga zaś, zlokalizowana na trzecim piętrze, jest połączona $\mathrm{z}$ parterem windą. Większy problem pojawia się jedynie w przypadku przechodzenia do sal ekspozycyjnych, do których najszybsza droga wiedzie bezpośrednio przez dziedziniec i wymaga pokonania kilkunastu schodów. Doświadczenie pokazuje jednak, że nasi goście z niespożytą energią deklarują absolutny brak konieczności poruszania się windą. Odzwierciedla to zresztą tendencję w nomenklaturze, jaką przyjmują studenci

\footnotetext{
${ }^{6}$ Ibidem.
} 
UTW, mówiąc o sobie „słuchacze”, „wiecznie młodzi”, ale odrzucając takie określenia, jak osoby stare czy starsze ${ }^{7}$. Mając zresztą na względzie dyskusję toczącą się wokół stygmatyzacji, jaką potencjalnie niosą ze sobą takie pojęcia, jak „osoba starsza' czy „senior”, podczas zajęć ze słuchaczami UTW idealnym rozwiązaniem okazuje się słowo „student". Nie tylko rozwiązuje ono problem marginalizowania czy utrwalania stereotypów opartych na kategoriach wiekowych, ale także buduje więź słuchaczy z Uniwersytetem, podkreślając ich przynależność do społeczności akademickiej.

Nawiązując współpracę z UTW, zdecydowaliśmy się na przygotowanie oferty dla dwóch kierunków: historia sztuki oraz historia i kultura Krakowa. Od roku 2015 roku lista tematów opracowanych przez Dział Oświatowy jest następująca:

- Co różni miedzioryt od akwaforty, czyli o technikach graficznych.

- Malowane światłem, czyli o technice powstawania witraży.

- Historia Uniwersytetu Jagiellońskiego podczas II wojny światowej.

- Symbolika żywiołów. Makaty marszałka Króla Słońce.

- Adam Mickiewicz w Krakowie? Nieobecna obecność wieszcza.

- Niebezpieczny wynalazek? O początkach drukarstwa w Krakowie.

- Co tak naprawdę wiemy o Koperniku?

- Profesorska galeria. Portrety uczonych z kolekcji Uniwersytetu Jagiellońskiego.

- Śladami wielkiego kompozytora - chopiniana w Collegium Maius.

- Dlaczego Kopernik nie nosił brody, czyli o wyglądzie studentów i profesorów w dawnych wiekach.

Większość tematów spotkała się z zainteresowaniem zarówno wśród studentów historii sztuki, jak i historii i kultury Krakowa. Dało się zauważyć, że w kolejnych latach część studentów regularnie zapisywała się na kolejne tematy, co motywowało nas do tworzenia nowych wykładów. Sukces wydaje się tym większy, iż od samego początku musieliśmy liczyć się z koniecznością pobierania opłaty za zajęcia w wysokości 5 zł.

Wiele czynników składa się na pozytywną ewaluację warsztatów przez słuchaczy, takich jak przestrzeń, udogodnienia, cena biletu czy elastyczność godzinowa. Pozostaje jednak jeszcze jedno, fundamentalne ogniwo decydujące o sukcesie, a mianowicie człowiek. Edukator, przewodnik, prowadzący, wykładowca - jakkolwiek byśmy tej osoby nie nazwali, to ona towarzyszy grupie od początku do końca, będąc odpowiedzialną nie tylko za przekazanie wiadomości, ale także za pomoc przy najbardziej przyziemnych rzeczach, takich jak znalezienie miejsca na sali. Lokalizacja, dzieła sztuki czy slajdy na prezentacji do pewnego stopnia mówią same za siebie, ale to człowiek buduje wokół nich narrację pozwalającą słuchaczom dogłębniej i świadomiej spojrzeć na dane zagadnienie czy muzealium. $Z$ jednej strony potrzeba cierpliwości przy tłumaczeniu roli chwiejaka $\mathrm{w}$ technice mezzotinty, $\mathrm{z}$ drugiej zaś przydałaby się nuta poetyckości przy opisie kolorów uwiecznionych w witrażowych szkiełkach. Wymagane są twarde fakty rzucające światło na narodziny drukarstwa w Polsce, ale także nieco

${ }^{7}$ M. Stec, Ł. Krzyżanowska, Młodość trzeciego wieku, „Studia Kulturoznawcze” 2013, nr 2 (4), s. 62.

${ }^{8}$ P.T. Kwiatkowski, B. Nessel-Łukasik, Seniorzy w muzeum. Raport, Narodowy Instytut Muzealnictwa i Ochrony Zbiorów, Warszawa 2019, s. 14. 
gawędziarska otoczka w przytaczaniu historii o żakach, którzy wydłużali czubki butów w średniowieczu, by nosić się modnie.

Wszystkie zajęcia prowadzone dla UTW zostały opracowane przez pracowników Działu Oświatowego zatrudnionych na etacie przewodników muzealnych. Są wśród nich osoby o wykształceniu historycznym, z dziedziny historii sztuki, polonistycznym, filologicznym czy pedagogicznym. Dobór tematów był naturalnie warunkowany kolekcją i historią uczelni. Ostatnio coraz więcej mówi się o edukacyjnym aspekcie aktywności muzeów, przedstawiając go jako doniosłą dziedzinę współczesnej muzeologii ${ }^{9}$. Renata Pater nazywa edukację muzealną „,wizytówką współczesnego muzealnictwa"10. Pracownicy Działu Oświatowego - mimo iż w aspekcie naukowym opierają się na materiale opracowanym przez specjalistów - dysponują cennym doświadczeniem: wyczuciem grupy, jej potrzeb i oczekiwań, wyczuciem wynikającym z wieloletniej pracy polegającej na stałym kontakcie z turystami i młodzieżą szkolną. Dobry edukator przekazuje fakty, dba o formę przystępną dla słuchacza, wykorzystuje pewne uproszczenia i humor, ale także aktywizuje publiczność, zadając pytania. Nawiązanie kontaktu z grupą, zachęcenie do podzielenia się wiedzą czy doświadczeniami tworzy atmosferę bezcennej otwartości, dającej satysfakcję zarówno seniorom, jak i samym prowadzącym.

\section{Zajęcia}

Na potrzeby badań przygotowano ankiety związane z przedstawionymi niżej wykładami.

\section{Niebezpieczny wynalazek? O poczatkach drukarstwa w Krakowie}

Zajęcia dotyczą historii wynalazku ruchomej czcionki i rozwoju sztuki drukarskiej w Krakowie. Część wykładu poświęcona jest Biblii Leopolity, czyli pierwszej drukowanej biblii katolickiej w języku polskim, obejmującej zarówno Stary, jak i Nowy Testament. W trakcie zajęć studenci mają możliwość zobaczenia oryginalnego klocka drzeworytniczego z Biblii Leopolity z przedstawieniem „Samsona i Dalili” z końca XVI wieku, specjalnie wyjmowanego w tym celu z przestrzeni magazynowych.

\section{Symbolika żywiotów. Makaty marszatka Króla Stońce}

Wykład jest poświęcony unikatowej kolekcji XVIII-wiecznych makat powstałych na zamówienie marszałka Francji François de Créquy, które trafiły do zbiorów MUJ dzięki rodzinie Pusłowskich. Dokumentacja fotograficzna prac konserwatorskich umożliwia

${ }^{9}$ A. Nadolska-Styczyńska, Nie tylko lekcje i oprowadzanie. Kilka uwag o polskiej edukacji muzealnej $i$ sposobach jej badania, „Journal of Urban Ethnology” 2016, nr 14, s. 97.

${ }^{10}$ R. Pater, Edukacja muzealna - wychowanie do aktywnego uczestnictwa w kulturze, „Parezja. Czasopismo Forum Młodych Pedagogów przy Komitecie Nauk Pedagogicznych PAN” 2017, nr 1 (7), s. 78. 
słuchaczom dokładniej zapoznać się z techniką powstawania makat. Po półgodzinnym wykładzie następuje oglądanie obiektów na żywo, kiedy to uczestnicy udają się z prowadzącym na tzw. Schody Rektorskie w Collegium Maius, gdzie można przyjrzeć się makatom z bliska.

\section{Profesorska galeria. Portrety uczonych z kolekcji Uniwersytetu Jagiellońskiego}

Kolekcja portretów profesorskich MUJ obejmuje obecnie ponad 300 dzieł tworzących wyjątkowy na tle europejskim zbiór pamiątek kultury materialnej. W trakcie zajęć słuchaczom przybliża się historię powstawania tych obrazów, a także przedstawia ich rolę w kształtowaniu tożsamości pośród społeczności akademickiej. Po części teoretycznej, której towarzyszy prezentacja multimedialna, słuchacze udają się na ekspozycję, gdzie w tzw. Sali z Lunetami oglądają zbiór portretów rzadziej udostępnianych zwiedzającym.

\section{Ankiety}

Wszystkie ankiety zostały przeprowadzone na końcu zajęć. Na udzielenie odpowiedzi studenci UTW mieli 10 minut. Poinformowano ich o celu ankiet oraz ich anonimowym charakterze. Dobitnie podkreślono, że podstawową ich wartością nie jest jak największa liczba poprawnych odpowiedzi, lecz wiarygodna statystyka pokazująca, które treści są mniej lub bardziej przyswajalne.

Formuła wszystkich trzech ankiet opiera się na wspólnym szablonie:

- Pytanie nr 1: „Prawda czy fałsz? Składa się z czterech twierdzeń, których prawdziwość należy ocenić wpisując krzyżyk w polu prawda lub fałsz. Za każde twierdzenie można było otrzymać po 1 punkcie. W sumie za zadanie można uzyskać 4 punkty. Poziom zadania został oceniony jako łatwy.

- Pytanie nr 2: „Które zdanie jest prawdziwe?” Składa się trzech twierdzeń, spośród których należy wybrać jedno. Za poprawną odpowiedź przysługują 2 punkty. Jeśli zdarzyło się, że zaznaczone zostały dwie odpowiedzi, w tym poprawna, przyznawano 1 punkt. Poziom zadania został oceniony jako średni.

- Pytanie nr 3: Rozpoznanie na podstawie ilustracji. Składa się z materiału ikonograficznego (dzieło sztuki omawiane podczas wykładu) oraz trzech odpowiedzi, spośród których należy wybrać jedną, odnoszącą się do ilustracji. W sumie za zadanie można było otrzymać 2 punkty. Poziom zadania został oceniony jako średni.

- Pytanie nr 4: Pytanie otwarte. Za poprawną odpowiedź można było uzyskać 1-3 punkty, w zależności od liczby podanych informacji. Poziom zadania został oceniony jako trudny.

- Pytanie nr 5: Pytanie otwarte. Za poprawną odpowiedź można było uzyskać 1-3 punkty, w zależności od liczby podanych informacji. Poziom zadania został oceniony jako trudny. 


\section{Analiza wyników}

W sumie w ankiecie można było uzyskać 14 punktów. Dla dalszej analizy istotny jest podział pytań na trzy kategorie: łatwe, średnie i trudne. Pytania łatwe (za 1 punkt) mają charakter zamknięty i wymagają od osoby rozwiązującej rozstrzygnięcia, czy zawarte w nim twierdzenie jest prawdziwe czy fałszywe. Twierdzenia opierają się na podstawowych informacjach prezentowanych w trakcie wykładu. Pytania średnie (za 2 punkty) wymagają od ankietowego wyboru jednej, prawidłowej treści spośród trzech podanych. Jedno z pytań na średnim poziomie trudności polega na rozpoznaniu źródła ikonograficznego, co jest warunkowane uważnym śledzeniem obiektów prezentowanych podczas zajęć. Drugie z kolei pytanie na średnim poziomie trudności składa się ze zdań fałszywych, choć opartych na pojęciach i nazwiskach pojawiających się podczas wykładu, co może łatwo wprowadzić w błąd. W końcu pytania trudne (za 3 punkty) mają charakter otwarty. Ankietowany musi się wykazać bardziej złożoną wiedzą i z pamięci przywołać nazwy, pojęcia bądź nazwiska, które padały podczas zajęć. Sumując, za pytania łatwe można było otrzymać maksymalnie 4 punkty, za pytania średnie 4 punkty oraz za pytania trudne 6 punktów.

Zgodnie z założeniami przyjętymi podczas opracowywania ankiety wynikiem wysoko satysfakcjonującym dla prowadzącego zajęcia jest liczba 11 punktów i więcej, tj. 79-100\%. Próg ten zakłada, że ankietowany wyniósł z wykładu nie tylko podstawową wiedzę na temat prezentowanych zagadnień, ale także zapamiętał bardziej złożone treści, co pozwoliło mu na udzielenie odpowiedzi w kategorii pytań otwartych. Punktacja została tak ustalona, że nawet w przypadku udzielenia samych dobrych odpowiedzi w pytaniach zamkniętych (8 punktów) do osiągnięcia progu 11 punktów potrzeba jeszcze 3 punktów.

Ponadto wyznaczono próg punktowy, poniżej którego ankieta w oczach prowadzącego jest niezadowalająca. Podczas tworzenia pytań przyjęto, że będzie to liczba punktów równa lub mniejsza od 7 , czyli 50\% punktów możliwych do uzyskania. Próg ten zakłada, że ankietowany nie wyniósł z wykładu podstawowej wiedzy, która pozwoliłyby mu na udzielenie najprostszych odpowiedzi w kategorii pytań zamkniętych. Liczbę 8-10 punktów zakwalifikowano jako dobrą. 


\section{Ankieta dla wykładu „Niebezpieczny wynalazek? O początkach drukarstwa w Krakowie"}

\begin{tabular}{|l|l|l|}
\hline 1. Prawda czy fałsz? & P & F \\
\hline $\begin{array}{l}\text { a) Za najstarszy druk na ziemiach polskich uznaje się } \\
\text { Kalendarz astronomiczny na } 1474 \text { rok. }\end{array}$ & \\
\hline $\begin{array}{l}\text { b) Pierwszym właścicielem drukarni polskiego pochodzenia } \\
\text { był Jan Januszowski. }\end{array}$ & \\
\hline c) Mikołaj Rej drukował u Macieja Wirzbięty. & \\
\hline d) Najstarszą mapę w Polsce wydrukował Florian Ungler. & \\
\hline 2. Które zdanie jest fałszywe? & \\
\hline a) Nazwa inkunabułu pochodzi od łacińskiego incunabula-w powijakach, \\
\hline b) Inkunabuły to książki drukowane do 1500 roku. \\
\hline c) Postylla Mikołaja Reja zalicza się do inkunabułów. \\
\hline 3. Kto jest autorem drzeworytu? \\
\hline a) Jost Amman
\end{tabular}

4. Która część dziela Andrzeja Frycza Modrzewskiego De republica emendanda została skonfiskowana przez cenzurę?

5. W którym polskim druku użyte zostały klocki drzeworytnicze z wittenberskiej Biblii Marcina Lutra? 
Ankieta dla wykładu „Profesorska galeria. Portrety uczonych z kolekcji Uniwersytetu Jagiellońskiego"

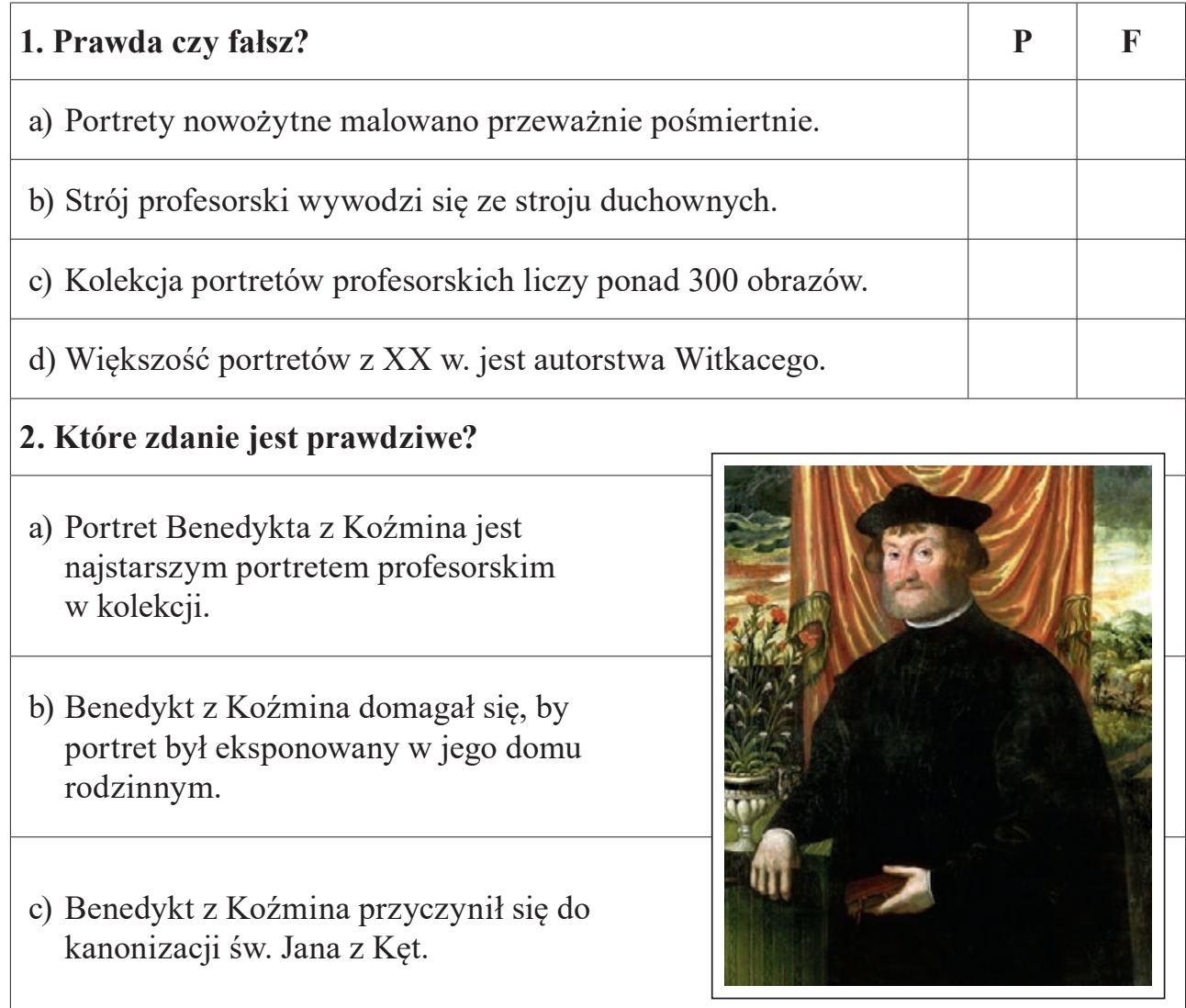

\section{Kto jest na portrecie?}

a) Wojciech Dąbrowski, nauczyciel Sobieskiego

b) Jan Brożek, astronom i matematyk, biograf Kopernika

c) Marian Sokołowski, twórca katedry historii sztuki na UJ

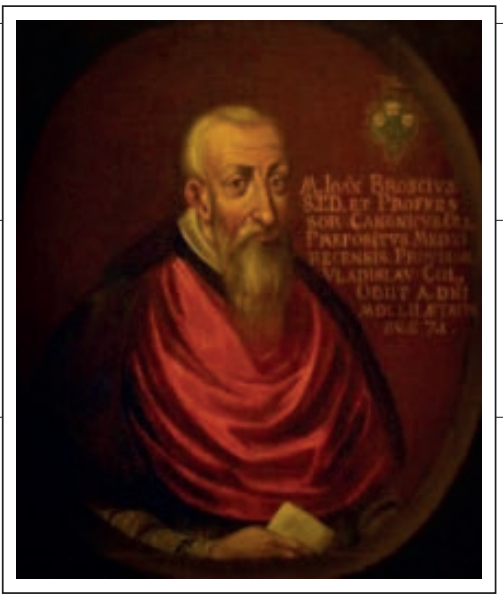


4. Gdzie zostal przedstawiony prof. Karol Estreicher senior?

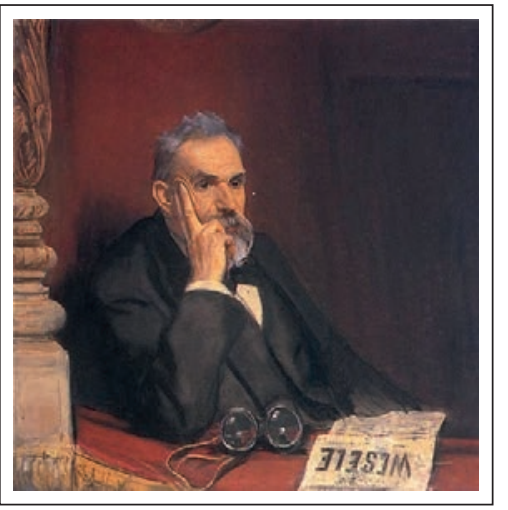

5. Kim był i z czego zasłynął prof. Karol Olszewski?

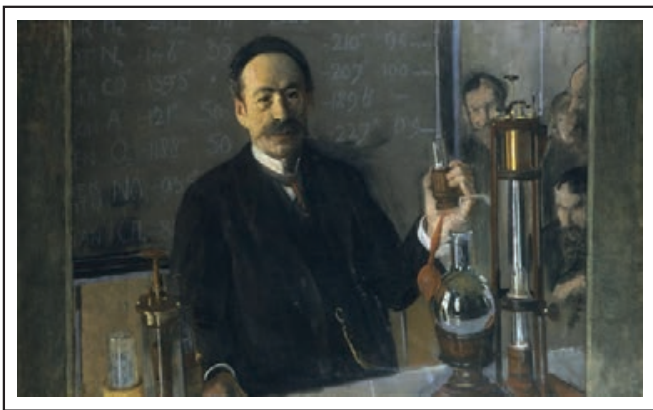


Ankieta dla wykładu „Symbolika żywiołów. Makaty marszałka Króla Slońce"

\begin{tabular}{|l|l|l|}
\hline 1. Prawda czy fałsz? & P & F \\
\hline a) Tapiseria to jednostronna, wielobarwna tkanina dekoracyjna. & & \\
\hline b) Marszałek de Créqui był uważany za nieudolnego dyplomatę. & \\
\hline c) W Muzeum UJ znajduje się 18 makat marszałka de Créqui. & \\
\hline d) Makaty są wykonane ściegiem krzyżykowym \\
i półkrzyżykowym.
\end{tabular}

4. Czym są makaty i gdzie powstawały?

5. Co przedstawia herb marszałka de Créqui? 
DRUKARSTWO: Liczba zdobytych punktów

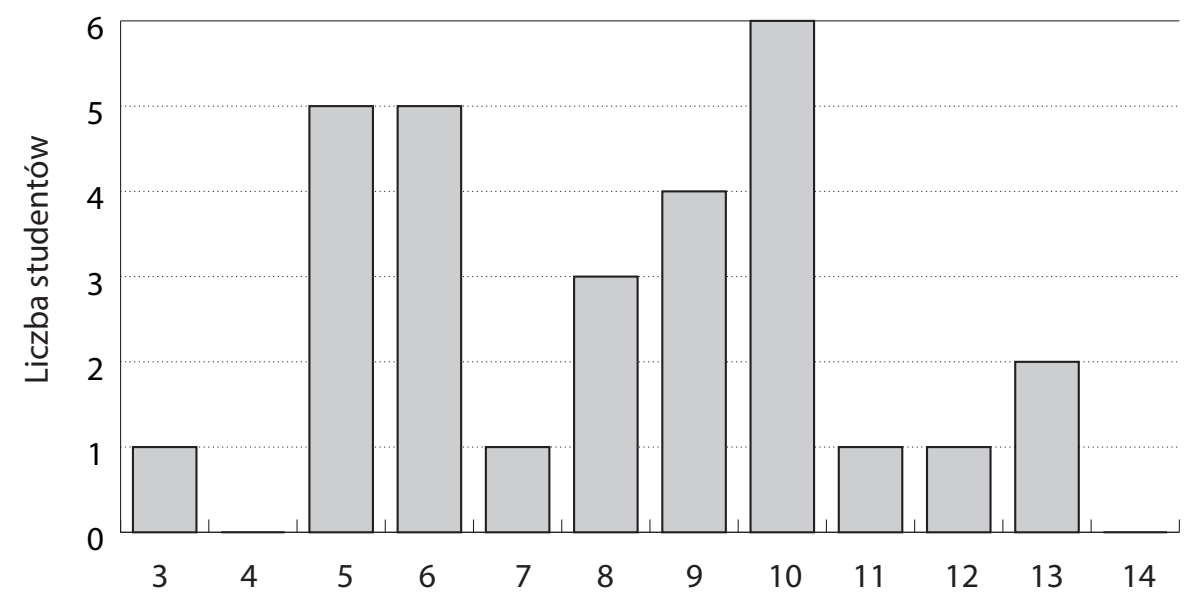

Liczba punktów

Wykres 1. Drukarstwo. Źródło: opracowanie własne

Liczba wszystkich uczestników wynosiła 23 osoby.

Najczęściej zdobywaną liczbą punktów było 10/14 (6 osób), co oznacza, że 26\% ankietowanych uzyskało wynik na poziomie $71 \%$. Dwa kolejne, najczęściej pojawiające się wyniki, to 9 i 8 punktów, tj. 17\% ankietowanych otrzymało wynik na poziomie $64 \%$ oraz $13 \%$ ankietowanych otrzymało wynik na poziomie $57 \%$.

Najniższą liczbę punktów zdobyła jedna osoba, czyli $4 \%$ ankietowanych otrzymało wynik na poziomie $21 \%$. Żadnej osobie nie udało się uzyskać maksymalnej liczby punktów.

Próg 11 punktów uznanych za wysoko satysfakcjonujący osiągnęly lub przekroczyły 4 osoby, tj. 17\% ankietowanych; 6 osób osiągnęlo wynik przyjęty za niezadowalający, tj. 26\% ankietowanych zdobyło 7 lub mniej punktów. 
MAKATY: Liczba zdobytych punktów

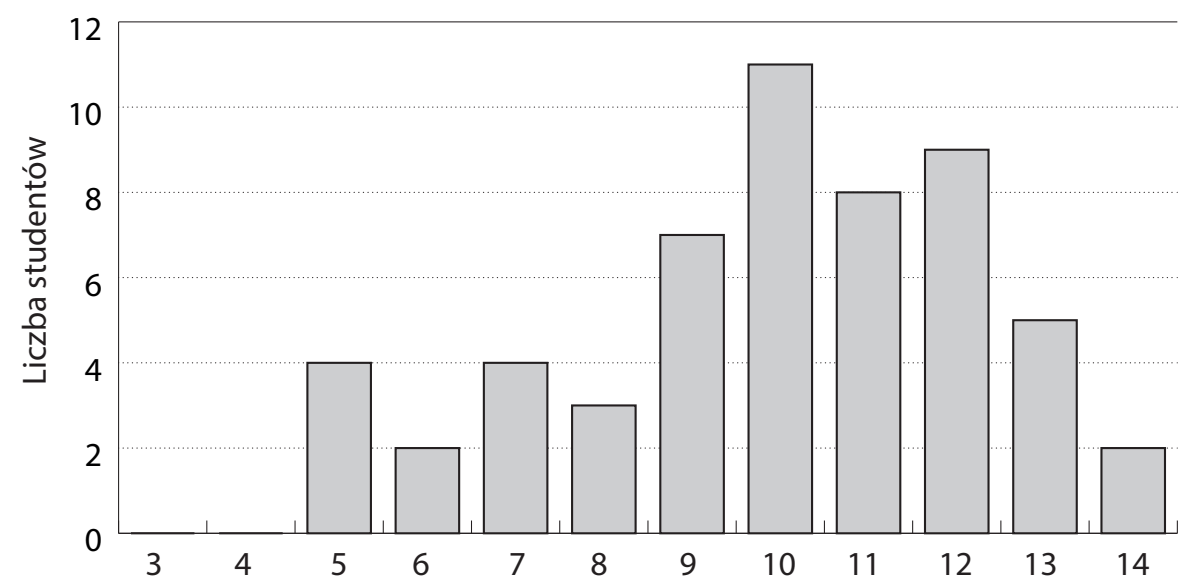

Liczba punktów

Wykres 2. Makaty. Źródło: opracowanie własne

Liczba wszystkich uczestników wynosiła 55 osób.

Najczęściej zdobywaną liczbą punktów było 10/14 (11 osób), co oznacza, że 20\% ankietowanych uzyskało wynik na poziomie $71 \%$. Dwa kolejne, najczęściej pojawiające się wyniki, to 12 i 11 punktów, tj. $16 \%$ ankietowanych otrzymało wynik na poziomie $86 \%$ oraz $14 \%$ ankietowanych otrzymało wynik na poziomie $79 \%$.

Najniższą liczbę punktów zdobyły 4 osoby, tj. 7\% ankietowanych otrzymało wynik na poziomie $36 \%$. Maksymalną liczbę punktów uzyskały 2 osoby, czyli $4 \%$ ankietowanych.

Próg 11 punktów uznanych za wysoko satysfakcjonujący osiągnęly lub przekroczyly 24 osoby, tj. 44\% ankietowanych; 10 osób osiągnęlo wynik przyjęty za niezadowalający, tj. 18\% ankietowanych zdobyło 7 lub mniej punktów. 
PORTRETY: Liczba zdobytych punktów

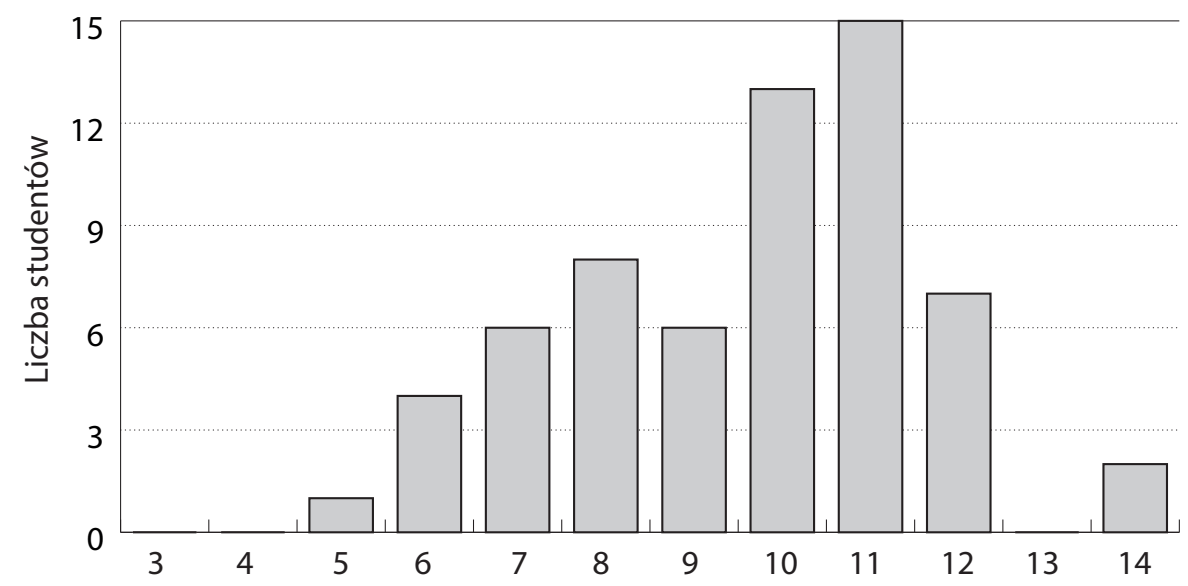

Liczba punktów

Wykres 3. Portrety. Źródło: opracowanie własne

Liczba wszystkich uczestników wynosiła 61 osób.

Najczęściej zdobywaną liczbą punktów było 11/14 (15 osób), co oznacza, że 25\% ankietowanych uzyskało wynik na poziomie $79 \%$. Dwa kolejne, najczęściej pojawiające się wyniki, to 10 i 8 punktów, tj. $21 \%$ ankietowanych otrzymało wynik na poziomie $71 \%$ oraz $13 \%$ ankietowanych otrzymało wynik na poziomie $58 \%$.

Najniższą liczbę punktów zdobyła jedna osoba, tj. 2\% ankietowanych otrzymało wynik na poziomie $36 \%$. Maksymalną liczbę punktów uzyskały 2 osoby, czyli 3\% ankietowanych.

Próg 11 punktów uznanych za wysoko satysfakcjonujący osiągnęly lub przekroczyły 24 osoby, tj. 39\% ankietowanych; 11 osób osiągnęlo wynik przyjęty za niezadowalający, tj. 18\% ankietowanych zdobylo 7 lub mniej punktów. 


\section{Wnioski}

Na podstawie zebranych statystyk możemy odpowiedzieć na trzy podstawowe pytania, które posłużą do zobrazowania przyswajalności wiedzy przez naszych słuchaczy:

1) Większość ankietowanych uzyskała wynik pozytywny (tj. dobry lub wysoko satysfakcjonujący) czy negatywny (niezadowalający)?

2) Jaki wynik (niezadowalający, dobry lub wysoko satysfakcjonujący) uzyskała największa liczba ankietowanych?

3) Jak wygląda stosunek wyników niezadowalających do wysoko satysfakcjonujących?

Oto jak plasują się odpowiedzi w zależności od tematu zajęć:

- Zajęcia poświęcone drukarstwu: Przeważająca większość ankietowanych uzyskała wynik uznany za dobry lub wysoko satysfakcjonujący (74\%). Najwięcej osób (57\%) uzyskało wynik uznany za dobry. Więcej osób uzyskało wynik niezadowalający (26\%) niż wysoko satysfakcjonujący (17\%).

- Zajęcia poświęcone makatom: Przeważająca większość ankietowanych uzyskała wynik uznany za dobry lub wysoko satysfakcjonujący (82\%). Najwięcej osób (44\%) uzyskało wynik uznany za wysoko satysfakcjonujący. Więcej osób uzyskało wynik wysoko satysfakcjonujący (44\%) niż niezadowalający (18\%).

- Zajęcia poświęcone portretom: Przeważająca większość ankietowanych uzyskała wynik uznany za dobry lub wysoko satysfakcjonujący (82\%). Najwięcej osób (43\%) uzyskało wynik uznany za dobry. Więcej osób uzyskało wynik wysoko satysfakcjonujący (44\%) niż niezadowalający (18\%).

Jakie wnioski możemy wyciągnąć na podstawie powyższych danych? Przede wszystkim na przykładzie wszystkich trzech tematów można z całą pewnością stwierdzić, że prowadzone w ten sposób wykłady mają duży sens, gdyż wzbogacają studentów UTW o wiedzę z pogranicza popularnonaukowej i specjalistycznej. Co do poziomu trudności zajęć, należy się pochylić się nad tematem drukarstwa, który okazał się najtrudniejszy dla naszych słuchaczy. Jak pokazały ankiety, grupa osób z wynikami niezadowalającym jest większa od grupy z wynikami wysoko satysfakcjonującymi, co jest dla nas istotną wskazówką co do kierunku, w jakim należy zmodyfikować treści prezentacji. Z kolei zajęcia poświęcone makatom mogą stanowić model wzorcowy dla innych wykładów, reprezentując idealne wyważenie między stopniem trudności zagadnienia a sposobem jego prezentacji.

\section{Podsumowanie}

Z praktyki muzealnej wiemy, że niektóre rezultaty pracy edukatora są widoczne od razu. Zainteresowanie zwiedzających, emocje towarzyszące zwiedzaniu, uśmiechy bądź wyrazy niezadowolenia, a czasem nawet znudzenia - to komunikaty, które docierając do nas w trakcie trwania zajęć, informują na bieżąco o poziomie satysfakcji odbiorców. Innym miarodajnym wskaźnikiem jest frekwencja na zajęciach cyklicznych. Powracający do nas słuchacze łaknący nowym tematów są cennym źródłem informacji o sensowności naszego programu. Badania nad publicznością muzealną okazują się niezbędne dla 
prawidłowo prowadzonej edukacji muzealnej. Jest to najlepsza motywacja do stałego poszerzania kompetencji i podążania za nowymi wzorcami i inspiracjami w muzealnych trendach działań edukacyjnych ${ }^{11}$.

Za cel stawiamy sobie przygotowanie słuchaczy do obcowania ze sztuką i historią, rozbudzanie zainteresowań tymi dziedzinami czy uwrażliwienie na wartości, które niesie ze sobą dziedzictwo kulturowe. To wszystko wiąże się z koniecznością przyswojenia konkretnej dawki wiedzy, którą proponujemy słuchaczom. Przeprowadzone ankiety pozwoliły na wstępne zobrazowanie, jak wiele informacji przeciętny słuchacz jest w stanie opanować. Z jednej strony dowiodły one słuszności naszych działań pokazując, jak wiele faktów zostaje zapamiętanych. Z drugiej strony badania uwypukliły treści, które nie do końca przemówiły do słuchaczy. Jeśli prowadzącemu zależy, by odbiorcy bardziej koncentrowali się na faktach, które - według ankiet - umknęły większości badanych, należy się zastanowić nad innym sposobem ich prezentacji bądź większą powtarzalnością.

Oczywiście w dążeniu do dostosowania programów edukacyjnych do odbiorcy należy zachować pewną równowagę. Ten temat porusza edukatorka muzealna Judith Mastai, twierdząc, że nie należy ślepo zaspokajać potrzeb czy oczekiwań zwiedzających. Według niej: „Jeśli praktyka edukacyjna wdraża wzorzec marketingowy, to podejście edukacyjne ogranicza się do podążania ścieżkami pragnień widza, wykorzystywania popularnej lub »przystępnej« tematyki, aby sprzedać doświadczenie muzealne"12. Traktowanie zatem zwiedzających jako źródła informacji o ich pragnieniach należy mądrze wykorzystywać, nie zatracając przy tym celu nadrzędnego, tj. popularyzacji konkretnej wiedzy. Wyzwanie polega na umiejętnym dobraniu narzędzi, by tę wiedzę przekazywać skutecznie.

\section{Bibliografia}

Głowacki P., Uniwersytet III wieku. Wyzwanie i szansa dla muzeum, „Muzealnictwo” 2013, nr 54. Kwiatkowski P.T., Nessel-Łukasik B., Seniorzy w muzeum. Raport, Narodowy Instytut Muzealnictwa i Ochrony Zbiorów, Warszawa 2019.

Mastai J., Nie ma czegoś takiego, jak zwiedzający [w:] Edukacja muzealna. Antologia ttumaczeń, Poznań 2010.

Nadolska-Styczyńska A., Nie tylko lekcje i oprowadzanie. Kilka uwag o polskiej edukacji muzealnej i sposobach jej badania, ,Journal of Urban Ethnology” 2016, nr 14.

Pater R., Edukacja muzealna - wychowanie do aktywnego uczestnictwa w kulturze, „Parezja. Czasopismo Forum Młodych Pedagogów przy Komitecie Nauk Pedagogicznych PAN”2017, nr 1 (7).

Po co seniorom kultura? Badania kulturalnych aktywności osób starszych. Raport Zwiazku Miast Polskich, Poznań 2012.

Poprawski M., Rozwój publiczności - seniorzy w instytucji kultury [w:] Rodziny/2015. Seniorki i seniorzy/2016 w instytucji kultury. Publikacja poseminaryjna cyklu ,Odbiorcy instytucji kultury”, red. M. Herkt, A. Mieszała, Poznań 2018.

Stec M., Krzyżanowska Ł., Młodość trzeciego wieku, „Studia Kulturoznawcze” 2013, nr 2 (4).

${ }^{11}$ A. Nadolska-Styczyńska, op. cit., s. 109.

12 J. Mastai, Nie ma czegoś takiego, jak zwiedzający [w:] Edukacja muzealna. Antologia thumaczeń, Poznań 2010, s. 296. 